\title{
TINGKAT PEMANFAATAN TUMBUHAN PENGHASIL WARNA PADA USAHA TENUN IKAT DI KABUPATEN SUMBA TIMUR
}

\author{
Utilization Level of Plat Produce Natural Dye \\ at Cloth Woven Business in East Sumba District \\ Murniati ${ }^{1}$ dan/and Mariana Takandjandji ${ }^{2}$ \\ Pusat Penelitian dan Pengembangan Hutan \\ Kampus Badan Litbang dan Inovasi, Jl. Gunung Batu No. 5, Kotak Pos 165 Bogor 16118, Jawa Barat, Indonesia \\ Telp. +62-251-8633234; Fax. +62-251-8638111 \\ Email: murni3008@yahoo.com¹,rambu_merry@yahoo.co.id ${ }^{2}$
}

Tanggal terima: 11 Desember 2014 Tanggal revisi: 27 Oktober 2015 Tanggal disetujui: 17 November 2015

\begin{abstract}
East Sumba cloth woven is colored using natural dye from plants. This study aimed to (1) identify plant producing natural dye in East Sumba, (2) its utilization level, and (3) its availability in nature. The research was conducted at four villages in 2013 and 2014 by using interview and focused group discussion with cloth woven handcrafter and also field observation. Five plant species namely Indigofera tinctoria $L$., Morinda citrifolia $L$., Symplocos $s p$., Aleurites moluccana (L.) Willd. and Erythrina sp. were used as dye material, binder, color preservatives and fabric softener. All plants were collected directly from nature, therefore the potency of these species were not yet available. Utilization level of I. tinctoria and M. citrifolia biomass as primary dye source were 49.3 and 246.7 ton per year, respectively. Whereas, utilization level of Symplocos $s p$. and A. moluccana as binder, color preservatives and fabric softener were each 246.7 and 49.3 ton per year. Cultivation of dye-producing plant and introduction of alternative dyes should be carried to meet the increasing demand of dyes.
\end{abstract}

Keywords: Cultivation, utilization, handcrafter, natural dye, cloth woven

\begin{abstract}
ABSTRAK
Pembuatan kain tenun ikat Sumba Timur sampai saat ini menggunakan pewarna alam yang dihasilkan dari tumbuhan. Penelitian ini bertujuan (1) mengidentifikasi jenis-jenis tumbuhan pewarna yang digunakan di Sumba Timur, (2) tingkat pemanfaatan, serta (3) ketersediaan di alam dan upaya untuk memenuhi kebutuhan yang terus meningkat. Penelitian dilakukan di empat kelurahan/desa pada tahun 2013 dan 2014 melalui metode wawancara dan diskusi kelompok terarah dengan pengrajin serta pengamatan di lapangan. Terdapat lima jenis tumbuhan yang digunakan pengrajin sebagai sumber, pengikat dan pengawet warna serta pelembut kain yaitu nila (Indigofera tinctoria L.), mengkudu (Morinda citrifolia L.), loba (Symplocos sp.), kemiri (Aleurites moluccana (L.) Willd.) dan dadap (Erytrina sp.). Kelima jenis tumbuhan tersebut dipungut langsung dari alam, tetapi data potensi jenis-jenis tersebut tidak tersedia. Tingkat pemanfaatan biomassa nila dan mengkudu sebagai sumber pewarna utama adalah 49,3 dan 246,7 ton per tahun. Sedangkan tingkat pemanfaatan loba dan kemiri sebagai bahan pengikat dan pengawet warna serta pelembut kain adalah 246,7 dan 49,3 ton per tahun. Kebutuhan biomassa tumbuhan penghasil warna yang terus meningkat perlu diimbangi dengan upaya budidaya jenis-jenis tersebut dan pengenalan serta penggunaan jenis-jenis pewarna alternatif.
\end{abstract}

Kata kunci: Budidaya, pemanfaatan, pengrajin, pewarna alam, tenun ikat

\section{PENDAHULUAN}

Sebagian besar flora atau jenis tumbuhan menghasilkan zat pewarna yang dapat digunakan untuk mewarnai kain. Lemmens \& WulijarniSoetjipto (1992) mengemukakan bahwa sebagian besar warna dapat diperoleh dari tumbuhan melalui pigmen yang terdapat pada jaringan dari berbagai bagian tumbuhan seperti akar, rimpang, pepagan, kayu, kulit kayu, daun, buah, biji, bunga dan kepala putik. Balai Pustaka \& Prosea (2009) melaporkan bahwa terdapat sekitar 62 jenis tumbuhan di Indonesia berpotensi untuk dikembangkan dan dijadikan sebagai pewarna alam antara lain Bixa orellana L. (kesumba), Garcinia mangostana L. (manggis), Impatiens 
balsamina L. (pacar air), Indigofera arrecta Hochst. (nila, tarum, indigo), Melastoma malabathricum L. (senduduk), Morinda citrifolia L. (mengkudu), Peltophorum pterocarpum (DC.) Backer (soga), Swietenia mahagoni (L.) Jacq. (mahoni), dan Uncaria gambir (Hunter) Roxb. (gambir).

Penggunaan zat pewarna alam di Indonesia telah dimulai sejak zaman penjajahan Belanda terutama untuk pewarnaan kain (Heyne, 1987). Sampai sekarang zat pewarna alam masih digunakan pada kain tenun ikat dengan corak tradisional. Pewarnaan menggunakan zat warna alam ini disukai karena menimbulkan efek khas yang tidak dapat ditiru oleh zat warna sintetik. Hal inilah yang mendukung kain tenun ikat sebagai produk ekslusif banyak diminati. Kulkarni et al. (2011) mengemukakan bahwa penggunaan pewarna alami telah meningkat beberapa kali lipat dalam beberapa tahun karena bersifat ramah lingkungan, sekalipun terdapat berbagai masalah dalam penggunaan pewarna alami, terutama dalam proses pencelupan yang sangat komplek, keterbatasan warna yang dihasilkan dan lain-lain. Selanjutnya Wanyama et al. (2014) melaporkan bahwa pewarna alami menjadi sangat penting dalam industri karena cenderung tidak beracun, ramah lingkungan dan karenanya permintaannya meningkat di seluruh dunia.

Menurut nDima (2007), masyarakat Sumba Timur sejak zaman pra sejarah Indonesia yaitu sekitar abad ke delapan sampai abad ke dua sebelum masehi telah membuat dan memakai sejenis kain tenun ikat yang dikenal dengan Kain Sumba yang dalam bahasa lokal disebut Hinggi yaitu busana adat laki-laki Sumba Timur berbentuk empat persegi panjang. Sedangkan busana adat untuk perempuan disebut Lawu atau sarung. Kegiatan menenun dilaksanakan secara manual dan tradisional yang menjadi kegiatan kaum perempuan. Pembuatan kain tenun Sumba Timur menggunakan zat pewarna alam yang berasal dari bagian tumbuhan penghasil warna (seperti akar, kulit kayu dan daun) yang merupakan salah satu Hasil Hutan Bukan Kayu (HHBK).

Dewasa ini kegiatan pembuatan kain tenun ikat Sumba Timur sudah berkembang pesat. Kegiatan menenun yang semula digunakan di lingkungan sendiri, kini telah berkembang menjadi usaha industri kerajinan yang komersial untuk dipasarkan baik lokal, nasional maupun internasional. Jumlah unit usaha meningkat tajam dari 628 pada tahun 2011 yang menyerap 1.309 tenaga kerja (Dinas Perindustrian dan Perdagangan Kabupaten Sumba Timur, 2011) menjadi 2.741 unit pada tahun 2012 yang menyerap 4.830 tenaga kerja (BPS Kabupaten Sumba Timur, 2012). Kapasitas produksi kain tenun ikat pada tahun 2011 tercatat 22.692 lembar dengan nilai produksi Rp 4,5 milyar (Dinas Perindustrian dan Perdagangan Kabupaten Sumba Timur, 2011). Data kapasitas produksi tahun 2012 tidak ditemukan, namun dari data jumlah unit usaha dapat diestimasi kapasitas produksi tahun 2012 yaitu 99.043 lembar.

Keberlanjutan usaha tenun ikat sangat bergantung pada ketersediaan bahan baku, khususnya sumber pewarna alam. Peningkatan jumlah unit usaha dan kapasitas produksi harus diikuti dengan peningkatan ketersediaan bahan baku pewarna alam berupa tumbuhan penghasil zat warna. Adalina (2013) mengemukakan bahwa zat warna alam mempunyai potensi pasar yang tinggi sebagai komoditas unggulan dalam memasuki pasar global dengan daya tarik yang unik, etnik dan eksklusif. Penelitian ini bertujuan mengidentifikasi jenis-jenis tumbuhan pewarna yang digunakan pada usaha kain tenun ikat di Kabupaten Sumba Timur, estimasi tingkat pemanfaatan dan ketersediaannya di alam serta upaya yang perlu dilakukan untuk memenuhi kebutuhan yang terus meningkat.

\section{METODOLOGI}

\section{A. Tempat dan Waktu Penelitian}

Penelitian dilakukan di Kabupaten Sumba Timur, meliputi empat kelurahan dan atau desa, yaitu Kelurahan Lambanapu dan Mauliru (Kecamatan Kambera), Desa Watu Hadang (Kecamatan Umalulu) dan Desa Kaliuda (Kecamatan Pahunga Lodu). Kelurahan Lambanapu dan Mauliru serta Desa Watu hadang adalah sentra produksi kain tenun ikat di Kabupaten Sumba Timur yang menggunakan tumbuhan pewarna alam. Sementara Desa Kaliuda merupakan satu-satunya desa di Kabupaten Sumba Timur penghasil kain tenun ikat yang mempunyai motif yang unik dan warna yang lebih cemerlang. Penelitian dilaksanakan pada bulan Juni 2013, bulan Februari dan bulan Juni 2014.

Kabupaten Sumba Timur terletak di Selatan khatulistiwa pada posisi $119^{\circ} 45^{\prime}-120^{\circ} 52^{\prime}$ Bujur Timur (BT) dan $9^{\circ} 16^{\prime}-10^{\circ} 20^{\prime}$ Lintang Selatan (LS). Luas wilayahnya $7.000,5 \mathrm{~km}^{2}$ terdiri atas 22 kecamatan. Jumlah penduduk 234.642 jiwa dan jumlah kepala keluarga (KK) sebanyak 50.734 dengan kepadatan penduduk 33 jiwa $/ \mathrm{km}^{2}$. 


\section{B. Metode Penelitian}

Pada penelitian ini dikumpulkan dua jenis data yaitu data sekunder dan data primer. Data sekunder berupa kondisi sosial ekonomi masyarakat, jumlah unit usaha tenun ikat, penyerapan tenaga kerja, pemberdayaan masyarakat, penyuluhan dan lain-lain. Data tersebut dikumpulkan di kantor Satuan Kerja Pemerintah Daerah (SKPD) terkait, meliputi Badan Pusat Statistik (BPS), Dinas Perindustrian dan Perdagangan, Dinas Kehutanan, Badan Pemberdayaan Masyarakat, Badan Pemberdayaan Perempuan dan Keluarga Berencana, dan Badan Pelaksana Penyuluhan Pertanian Perikanan dan Kehutanan (BP4K). Data primer yang dikumpulkan meliputi jenisjenis tumbuhan penghasil warna yang digunakan, tingkat pemanfaatan, tingkat ketersediaannya di alam dan upaya budidaya yang sudah dan yang perlu dilakukan.

Data primer diperoleh melalui wawancara menggunakan kuesioner sebagai pemandu, diskusi kelompok terarah (Focused Group Discussion/FGD) dan observasi lapangan. Wawancara dilakukan di tiga desa (kelurahan) yaitu Lambanapu, Mauliru dan Watu Hadang. Penentuan responden dilakukan secara berjenjang. Tahap pertama secara purposif, yaitu masyarakat yang berprofesi sebagai pengrajin kain tenun ikat, baik sebagai pekerjaan utama maupun sebagai pekerjaan sampingan. Tahap kedua secara acak atau random yaitu pengrajin yang dapat ditemui atau pengrajin yang mempunyai waktu senggang dan bersedia diwawancarai di ketiga desa lokasi penelitian. Pengumpulan data primer di Desa Kaliuda dilakukan dengan metode diskusi kelompok terarah dengan tiga kelompok kecil responden, jumlah responden 6 sampai 8 per kelompok. Hal ini dilakukan karena kepala desa mengumpulkan pengrajin di balai desa, dimana sebelum FGD dilakukan, tim peneliti diminta untuk memberikan arahan dan pembinaan kepada pengrajin sehubungan dengan tumbuhan penghasil zat warna sebagai bahan baku pewarnaan kain tenun ikat. Penentuan pengrajin yang mengikuti FGD adalah berdasarkan perwakilan dari masing-masing dusun secara proporsional. Jumlah responden sebanyak 60 dengan rincian 27 responden di Kecamatan Kambera (15 responden di Kelurahan Lambanapu dan 12 responden di Kelurahan Mauliru), 12 responden di Desa Watu Hadang (Kecamatan Umalulu) dan 21 responden di Desa Kaliuda (Kecamatan Pahunga Lodu).

Data tingkat pemanfaatan tumbuhan penghasil warna didekati dengan satuan lokal yang digunakan oleh penenun yaitu karung dan ikat kemudian dikonversi ke kilogram atau ton. Tingkat pemanfaatan jenis-jenis tumbuhan penghasil zat warna tingkat kabupaten diestimasi dengan dua pendekatan, yaitu: 1) dari data primer hasil wawancara tentang rata-rata kebutuhan bahan tumbuhan untuk mewarnai benang sebagai bahan dasar pembuatan kain tenun ikat, dan 2) data primer dan sekunder yaitu data kapasitas produksi kain tenun ikat tingkat Kabupaten Sumba Timur pada tahun 2011 dan 2012.

Data tingkat ketersediaan tumbuhan penghasil warna di alam dikumpulkan melalui data sekunder dan primer. Data primer diperoleh dari hasil wawancara dan diskusi kelompok terarah dengan responden pengrajin tentang kecenderungan ketersediaan tumbuhan pewarna di alam melalui perbandingan 10 tahun yang lalu, sekarang dan prediksi 10 tahun ke depan.

\section{Analisis Data}

Data yang diperoleh, baik data primer maupun sekunder diolah dengan tabulasi silang untuk memperoleh nilai rata-rata dan dibahas secara deskriptif.

\section{HASIL DAN PEMBAHASAN}

\section{A. Kondisi Sosial Ekonomi Masyarakat dan Biofisik Kabupaten Sumba Timur}

Tingkat pendidikan masyarakat di Kabupaten Sumba Timur masih sangat rendah. Dari total penduduk yang berumur 10 tahun ke atas, terdapat $70,44 \%$ hanya berpendidikan SD baik tamat ataupun tidak tamat (tidak berijazah). Selanjutnya hanya $25,35 \%$ dari penduduk yang berumur 10 tahun ke atas yang berpendidikan sekolah menengah (pertama dan atas) dan hanya $4,21 \%$ yang berpendidikan tinggi (diploma dan sarjana).

Pendapatan perkapita atau Produk Domestik Regional Bruto (PDRB) Kabupaten Sumba Timur relatif rendah yaitu $\mathrm{Rp}$ 6.063.068,- namun pertumbuhan ekonominya cukup tinggi yaitu $12,72 \%$. Pendapatan Daerah Regional Bruto (PDRB) dan pertumbuhan ekonomi Kabupaten Sumba Timur lebih tinggi dibandingkan PDRB dan pertumbuhan ekonomi Provinsi Nusa Tenggara Timur yang nilainya berturut-turut adalah Rp 5.515.943 dan 12,23\% (BPS Kabupaten Sumba Timur, 2012a).

Ekosistem savana mendominasi daratan Sumba Timur. Dilaporkan bahwa $68,16 \%$ dari luas 
wilayah Kabupaten Sumba Timur atau 477.157 ha merupakan ekosistem savana (Gana, 2007). Demikian pula Umroni (2010) menyebutkan bahwa savana mendominasi daratan di Kabupaten Sumba Timur.

Kabupaten Sumba Timur mempunyai 237.831 ha kawasan hutan yang terdiri atas Hutan Lindung 75.756 ha (31,85\%), Hutan Produksi 37.695 ha $(15,85 \%)$, Hutan Produksi Terbatas 10.116 ha $(4,25 \%)$, Taman Nasional 65.315 ha $(27,46 \%)$, Hutan Produksi yang di Konversi 48.949 ha $(20,58 \%)$ (Dinas Kehutanan Kabupaten Sumba Timur, 2014). Sebagian kawasan hutan tersebut berupa ekosistem savana (Banilodu \& Saka, 1993).

Ekosistem savana dengan kondisi tanah berbatu dan solum tipis ditumbuhi oleh jenis-jenis flora yang tahan terhadap kekeringan dan lahan marginal. Beberapa jenis pohon dan semak yang tumbuh di ekosistem savanna secara sporadis merupakan tumbuhan penghasil warna yang digunakan oleh masyarakat Sumba untuk mewarnai kain tenun ikat, seperti wora atau nila (Indigofera tinctoria L.) dan kombu atau mengkudu (Morinda citrifolia L.).

Data potensi jenis-jenis tumbuhan penghasil pewarna secara khusus tidak ditemukan, namun Banilodu \& Saka (1993) melaporkan bahwa kawasan hutan dataran rendah Luku Malolo di Kabupaten Sumba Timur mempunyai kekayaan jenis pohon sebanyak 34 jenis dengan kerapatan rata-rata 98,4 pohon/ha (diameter $>2 \mathrm{~cm}$ ). Dilaporkan pula bahwa pengambilan kulit atau teras kayu untuk tujuan ekonomi dan obat tradisional banyak ditemukan dalam kawasan hutan di Pulau Sumba.

\section{B. Tumbuhan Penghasil Warna}

\section{Jenis-jenis tumbuhan penghasil warna}

Sampai saat ini warna yang banyak digunakan pengrajin di Sumba Timur adalah warna merah, hitam dan biru. Bahan pewarna alam yang digunakan berasal dari bagian tumbuhan (daun, batang, buah, biji, akar dan kulit kayu). Dari hasil wawancara dengan pengrajin diketahui bahwa ada 20 jenis tumbuhan yang digunakan sebagai sumber pewarna oleh pengrajin kain tenun ikat di Kabupaten Sumba Timur (Lampiran 1), namun yang banyak digunakan hanya lima jenis (Tabel 1) dengan warna yang dihasilkan adalah merah, hitam dan biru. Empat jenis diantaranya berupa pohon hutan (hasil hutan bukan kayu/HHBK), dimana bagian yang dimanfaatkan adalah buah, akar dan kulit kayu (pepagan) serta satu jenis berupa semak atau perdu yaitu nila (Indigofera tinctoria L.). Adalina et al. (2013) melaporkan bahwa pengrajin kain tenun ikat di Sumba Timur menggunakan Indigofera tinctoria sebagai bahan utama pewarna biru dalam pewarnaan kain tenun ikat dan menambahkan abu dari berbagai akar tanaman untuk perekat atau pengikat warna. Cunningham et al. (2011a) mengemukakan bahwa penenun di Indonesia bagian Timur antara lain Pulau Flores, Sumba dan Sabu-Raijua secara alami terus mencelup kain dengan pewarna alami sebagai tradisi, menggunakan berbagai spesies Symplocos yang mengandung hyperaccumulators senyawa aluminium. Haning (2012) juga melaporkan bahwa masyarakat di Sumba Timur dan Sumba Barat tetap menggunakan pewarna alami dalam memproduksi kain tenun dimana kualitas produksi sangat ditentukan oleh jenis pewarna dan desain serta teknik pewarnaan.

Jenis nila (Indigofera tinctoria) umumnya dipungut pengrajin di kebun atau di padang-padang yang tumbuh secara alami. Menurut Lemmens \& Wulijarni-Soetjipto (1999), marga Indigo-fera mencakup perdu, perdu kecil dan terna (yang kemudian berkayu di pangkal batangnya), tingginya bervariasi 1 sampai $3 \mathrm{~m}$, dapat tumbuh dari 0 sampai $1.650 \mathrm{~m}$ dpl. Secara alami, jenis-jenis Indigofera tumbuh di tempat terbuka dengan sinar matahari penuh. Dari pengamatan di lapangan, jenis yang umumnya digunakan sebagai bahan pewarna biru atau hitam di Kabupaten Sumba Timur adalah I. tinctoria L., berupa semak/terna dengan tinggi sampai satu meter. Selanjutnya Lemmens \& Wulijarni-Soetjipto (1999) menyatakan bahwa produksi hijauan I. tinctoria berkisar antara 10 sampai 13 ton/ha, bervariasi menurut tapak, musim dan cara budidayanya. Menurut Herdiawan \& Krisnan (2014), produksi I. tinctoria L. segar sebesar 33,339 ton/ha/tahun dan 8,423 ton/ha/tahun bahan kering.

Akar mengkudu (Morinda citrifolia) dipungut pengrajin dari pohon yang tumbuh di padang-padang secara alami. Menurut Lemmens \& Wulijarni-Soetjipto (1999), M. citrifolia L. adalah tumbuhan berupa perdu atau pohon kecil yang bengkok-bengkok dengan tajuk merunjung, tinggi 3-10 m, memiliki akar tunggang yang tertancap dalam, pepagannya berwarna cokelat keabu-abuan atau cokelat kekuning-kuningan. Pepagan akar mengkudu mengandung bahan pokok pewarna morinda yang merupakan bentuk hidrolisis (merah) dari glikosida morindin. Konsentrasi zat ini mencapai $0,25-0,5 \%$ dari bobot basah pepagan akar morinda yang berumur 3-5 tahun. Mengkudu yang ditanam dengan jarak tanam 1,2 x 1,2 $\mathrm{m}$ dapat menghasilkan pepagan akar $500-1.000 \mathrm{~kg} / \mathrm{ha}$. 
Tabel(Table) 1. Jenis-jenis tumbuhan yang banyak dimanfaatkan sebagai pewarna kain tenun ikat di lokasi penelitian (Plant species that much used as natural dye for coloring cloth at the research site)

\begin{tabular}{|c|c|c|c|c|}
\hline \multirow[b]{2}{*}{ No. } & \multicolumn{2}{|c|}{ Jenis tumbuhan (Plant species) } & \multirow[b]{2}{*}{$\begin{array}{c}\text { Bagian yang } \\
\text { dimanfaatkan } \\
\text { (Parts being used) }\end{array}$} & \multirow[b]{2}{*}{$\begin{array}{c}\text { Warna yang } \\
\text { dihasilkan } \\
\text { (Produced colour) }\end{array}$} \\
\hline & $\begin{array}{l}\text { Nama daerah } \\
\text { (Local name) }\end{array}$ & $\begin{array}{l}\text { Nama ilmiah dan family } \\
\text { (Scientific name and the } \\
\text { family) }\end{array}$ & & \\
\hline 1. & Wora atau nila & $\begin{array}{l}\text { Indigofera tinctoria } \text { L./ } \\
\text { Leguminoseae }\end{array}$ & Daun, batang, biji & Biru-hitam \\
\hline 2. & Kombu atau mengkudu & $\begin{array}{l}\text { Morinda citrifolia L./ } \\
\text { Rubiaceae }\end{array}$ & Akar & Merah \\
\hline 3. & Loba & $\begin{array}{l}\text { Symplocos sp./ } \\
\text { Symplocaceae }\end{array}$ & $\begin{array}{l}\text { Kulit batang/cabang } \\
\text { (pepagan) dan daun } \\
\text { kering }\end{array}$ & $\begin{array}{l}\text { Pengikat warna } \\
\text { (mordan) }\end{array}$ \\
\hline 4. & Kawilu atau kemiri & $\begin{array}{l}\text { Aleurites moluccana (L.) } \\
\text { Willd. / Euphorbiaceae }\end{array}$ & Daging buah & $\begin{array}{l}\text { Penguat/pengawet } \\
\text { warna }\end{array}$ \\
\hline 5. & Walakari atau dadap & $\begin{array}{l}\text { Erythrina sp. / } \\
\text { Leguminoseae }\end{array}$ & $\begin{array}{l}\text { Kulit batang (bagian } \\
\text { dalam) }\end{array}$ & Pelembut kain \\
\hline
\end{tabular}

Sumber (Source): Data primer (Primery data)

Symplocos sp. berupa perdu sampai pohon. Menurut Hadi (2013), terdapat dua jenis loba yaitu loba manu (Symplocos fasciculata) dan loba wawi (Symplocos chochichinensis). Kedua jenis tumbuhan tersebut hidup pada ketinggian 600-1.200 m dpl terutama di Pulau Sumba dan Flores. Loba manu (S. fasciculata) kebanyakan dijumpai berupa perdu, dengan tinggi maksimal 14 meter, diameter batang mencapai $30 \mathrm{~cm}$. Bagian daun dan rantingnya halus dengan daun 6-9 pasang urat yang tidak sejajar, braktea dan gagang daunnya hanya membungkus bagian bakal buah. Kulit batangnya halus berwarna putih dengan bercak-bercak berwarna cokelat dan hitam. Buah loba manu berukuran sebesar kelereng, berwarna hijau ketika muda dan berangsur angsur menjadi merah hitam ketika masak. Loba wawi (S. chochichinensis) jarang dijumpai berupa pohon, rantingnya berbulu (pilose) jarangjarang, daunnya berselang atau pada cabang pokok tersusun spiral berukuran $5 \times 4,5 \mathrm{~cm}$ dengan 6-8 pasang urat daun. Buahnya sebesar biji kapuk, berwarna hijau ketika muda dan menjadi hitam apabila sudah masak. Kulit batang loba wawi kasar dan berwarna cokelat gelap. Secara umum, perbedaan dari keduanya dapat dilihat dari ukuran dan penampakan daunnya, loba wawi terlihat memiliki ukuran daun yang lebih besar dan lebih mengkilap bahkan cenderung terang (abu-abu), sedangkan loba manu memiliki daun berukuran relatif kecil dan berwarna hijau gelap. Selain itu permukaan dan corak warna kulit batang kedua jenis loba dapat dibedakan.

Dari informasi persebaran geografinya dan dari pengamatan di lapangan diketahui bahwa jenis yang digunakan di Sumba Timur dengan nama daerah "loba" adalah Symplocos fasciculata Zoll. dengan perawakan perdu atau pohon kecil, tinggi 9-22 $\mathrm{m}$ dengan diameter batang mencapai $30 \mathrm{~cm}$. Lemmens \& Wulijarni-Soetjipto (1999) melaporkan bahwa bagian dalam pepagan (batang) jenis ini mengandung sejumlah besar aluminium (mencapai 50\% dari abu) yang berfungsi sebagai mordan (garam logam) untuk bahan pengikat dalam pewarnaan kain. Penggunaan kulit batang loba sebagai mordan memiliki beberapa kelebihan diantaranya adalah hasil pewarnaan tidak mudah luntur, penyerapan warna oleh bahan katun lebih besar sehingga warna yang dihasilkan terlihat lebih terang.

Hadi (2013) melaporkan bahwa di kawasan hutan Desa Tendambera, Kecamatan Nangapanda, Kabupaten Ende, Provinsi NTT dengan luas sekitar 50 ha, produksi kulit batang loba ratarata $450 \mathrm{~kg} /$ tahun atau $9 \mathrm{~kg} / \mathrm{ha} /$ tahun. Produksi daun gugur loba rata-rata sebesar $90 \mathrm{~kg} / \mathrm{ha} / \mathrm{tahun}$ pada pengukuran dengan kerapatan 63,64 pohon/ ha. Dengan demikian total biomasa (kulit batang dan daun gugur) loba yang dihasilkan adalah 99 $\mathrm{kg} / \mathrm{ha} /$ tahun. Sebelumnya, Hadi (2010) melaporkan bahwa potensi jenis loba di lokasi tersebut pada tingkat pohon 3,33 batang/ha, pada tingkat tiang 33,33 batang/ha, pancang $10 \mathrm{batang} / \mathrm{ha}$ dan tingkat semai sebanyak 13.500 semai/ha.

Kemiri (Aleurites moluccana (L.) Willd.) berupa pohon besar, tinggi mencapai $40 \mathrm{~m}$. Pepagannya berwarna abu-abu dan sedikit kasar. Perbanyakan kemiri dilakukan dengan menggunakan biji. Produksi buah kemiri berkisar antara $30-80 \mathrm{~kg} /$ pohon/tahun atau rata-rata $55 \mathrm{~kg} /$ 
pohon/tahun dengan kandungan minyak sekitar 15-20\% (Krisnawati et al., 2011). Daging buah kemiri digunakan untuk bumbu masak, obatobatan, bahan baku cat, sabun dan kosme-tik. Pada kerajinan tenun ikat di Sumba Timur daging buah kemiri digunakan sebagai bahan campuran dalam pewarnaan sebagai penguat dan pengawet warna. Subagiyo (2008) melaporkan bahwa bahan-bahan campuran dalam pewarnaan dapat meningkatkan afinitas molekul zat warna pada serat benang dan secara kimia dapat membantu pendifusian molekul atau zat warna merah ke dalam sel-sel serat benang.

Dadap (Erythrina variegata L.) menyebar secara alami di daerah pantai terutama di dekat muara sungai. Pohon ini tumbuh baik di daerah lembab dan setengah kering, dengan curah hujan 800-1.500 mm per tahun dan 5-6 bulan basah. Meskipun mampu hidup pada berbagai kondisi tanah, dadap menyukai tanah-tanah yang dalam, sedikit berpasir dan berdrainase baik. Dadap mampu tumbuh pada tanah-tanah bergaram dan tanah kapur berkarang dengan kisaran $\mathrm{pH}$ tanah antara 4,5-8,0 (Heyne, 1987). Pohon dadap berukuran sedang, mencapai tinggi 15-20 m dan diameter batang $40 \mathrm{~cm}$. Kulit batang bagian luar keabu-abuan, berserabut dan berduri. Cabang menyebar, berduri hitam. Daun lebar, ujung meruncing, dan berdaging. Bunga berwarna merah terang dan berukuran besar. Buahnya berupa polong berukuran panjang $10-25 \mathrm{~cm}$, diameter 1,5-2 $\mathrm{cm}$ dan 1 polong berisi $5-10$ butir biji yang berbentuk bulat telur, coklat, merah atau ungu mengkilap (Heyne, 1987). Perbanyakan dapat dilakukan melalui biji atau stek. Kulit batang Erythrina variegata mengandung saponin, flavonoid dan polifenol yang berperan dalam pewarnaan kain. Disamping itu kulit batangnya juga mengandung alkaloida (Cunningham, 2011b).

Indrianingsih \& Darsih (2013) melaporkan bahwa sumber pewarna alami ditemukan berlimpah di alam, namun mempunyai banyak kelemahan seperti warna yang dihasilkan mudah memudar, tidak ada jaminan ketersediaan bahan baku secara berkelanjutan, warnanya kurang bervariasi dan lain-lain.

\section{Tingkat pemanfaatan}

Sebagaimana dijelaskan di muka, terdapat lima jenis tumbuhan yang banyak digunakan sebagai sumber pewarna oleh pengrajin kain tenun ikat di Kabupaten Sumba Timur (Tabel 1). Namun, hanya empat jenis tumbuhan yang dapat dihitung tingkat pemanfaatannya. Tingkat pemanfaatan dadap (Erytrina sp.) belum dapat di- hitung karena ukuran yang digunakan pengrajin sangat bervariasi. Estimasi tingkat pemanfaatan jenis-jenis tumbuhan penghasil warna berdasarkan dua pendekatan adalah sebagai berikut:

a. Dari data primer yaitu dari hasil wawancara tentang rata-rata kebutuhan bahan tumbuhan untuk mewarnai satu kepala benang sebagai bahan dasar pembuatan kain tenun ikat (catatan: kepala benang adalah satuan yang digunakan oleh pengrajin untuk menyatakan satu unit benang). Rata-rata produktivitas kerja pengrajin di empat kelurahan/desa lokasi penelitian menurut produk yang dihasilkan adalah 8,94 unit benang per tahun (Tabel 2), artinya setiap pengrajin dapat mengerjakan sebanyak 8,94 unit atau dibulatkan menjadi sembilan unit benang per tahun. Ada tiga jenis produk tenun ikat yang dihasilkan, yaitu selendang dengan rata-rata ukuran $1 \times 0,6 \mathrm{~m}$, sarung dengan ukuran $2 \times 1 \mathrm{~m}$ sampai $2,5 \times 1$ $\mathrm{m}$ dan kain dengan ukuran $3 \times 1,5 \mathrm{~m}$. Penggunaan warna merah dan biru atau hitam hampir sama banyak, sehingga dari rata-rata sembilan unit benang, diasumsikan 4,5 unit benang diwarnai merah menggunakan pewarna jenis mengkudu dan 4,5 unit benang diwarnai hitam atau biru menggunakan pewarna jenis nila. Jenis loba dan kemiri digunakan untuk semua benang karena fungsinya sebagai pengikat atau pengawet warna dan pelembut kain. Dengan demikian dapat dihitung rata-rata tingkat pemanfaatan empat jenis tumbuhan penghasil warna oleh seorang pengrajin (Tabel 3).

Data pada Tabel 3 menunjukkan bahwa tingkat pemanfaatan biomassa nila dan mengkudu untuk Kabupaten Sumba Timur pada tahun 2012 bertutut-turut adalah 49,34 dan 246,69 ton per tahun. Selanjutnya tingkat pemanfaatan loba dan kemiri adalah 246,9 dan 49,34 ton per tahun. Tingkat pemanfaatan biomasa empat jenis tumbuhan pewarna tersebut diperoleh dari jumlah unit usaha kerajinan tenun di Kabupaten Sumba Timur yang ada pada tahun 2012 yaitu 2.741 unit (BPS Kabupaten Sumba Timur, 2012) dikalikan dengan tingkat pemanfaatan per pengrajin (unit usaha) per tahun.

b. Dari data primer dan sekunder. Sebagaimana dijelaskan pada Bab Pendahuluan bahwa kapasitas produksi kain tenun ikat tingkat Kabupaten Sumba Timur pada tahun 2011 adalah 22.692 lembar. Dari data peningkatan jumlah unit usaha pada tahun 2011 dan 2012 
Tabel(Table)2. Rata-rata produktivitas kerja pengrajin (unit benang per tahun) menurut jenis produk yang dihasilkan di lokasi penelitian (Average labor productivity (unit of thread per year) of handcrafter according to type of the product at the research sites)

\begin{tabular}{|c|c|c|c|c|}
\hline \multirow{2}{*}{$\begin{array}{l}\text { Lokasi penelitian, jumlah } \\
\text { responden (Research sites, } \\
\text { number of respondent) }\end{array}$} & \multicolumn{4}{|c|}{$\begin{array}{c}\text { Rata-rata produktivitas kerja pengrajin per jenis produk per tahun } \\
\text { (Average labor productivity of handcrafter for type of product per year) } \\
\text { (unit benang/unit of thread) }\end{array}$} \\
\hline & $\begin{array}{c}\text { Selendang } \\
(\text { Scarf })\end{array}$ & $\begin{array}{l}\text { Sarung } \\
\text { (Sheath) }\end{array}$ & $\begin{array}{l}\text { Kain } \\
(\text { Cloth })\end{array}$ & $\begin{array}{r}\text { Jumlah } \\
\text { (Total) } \\
\end{array}$ \\
\hline $\begin{array}{l}\text { Kelurahan Lambanapu } \\
\text { (Lambanapu Village) }(\mathrm{n}=15) \\
\text { Kelurahan Mauliru }\end{array}$ & 2,77 & 2,67 & 3,23 & 8,67 \\
\hline $\begin{array}{l}\text { (Mauliru Village })(\mathrm{n}=12) \\
\text { Desa Watu Hadang }\end{array}$ & 2,80 & 3,40 & 3.30 & 9,50 \\
\hline $\begin{array}{l}\text { (Watu Hadang Village) }(\mathrm{n}=12) \\
\text { Desa Kaliuda }\end{array}$ & 1,28 & 2,46 & 1,83 & 5,57 \\
\hline$($ Kaliuda Village $)(\mathrm{n}=21)$ & 3,00 & 5,00 & 4,00 & 12,00 \\
\hline Rata-rata (Average) $(\mathrm{n}=60)$ & 2,47 & 3,38 & 3,09 & 8,94 \\
\hline
\end{tabular}

Sumber (Source): Data primer (Primery data)

Keterangan (Remarks): $\mathrm{n}=$ Jumlah responden (Number of respondent)

Tabel (Table) 3. Rata-rata tingkat pemanfaatan biomassa empat jenis tumbuhan penghasil warna oleh pengrajin di lokasi penelitian (Average utilization level of biomass of four plant species produce natural dye by handcrafter at the research site)

\begin{tabular}{|c|c|c|c|c|c|c|}
\hline \multirow[t]{2}{*}{ No. } & \multirow[t]{2}{*}{$\begin{array}{c}\text { Jenis } \\
\text { (Species) }\end{array}$} & \multirow[t]{2}{*}{$\begin{array}{l}\text { Rata-rata } \\
\text { penggunaan } \\
\text { per unit } \\
\text { benang } \\
\text { (average } \\
\text { utilization for } \\
\text { each thread } \\
\text { unit) }\end{array}$} & \multirow[t]{2}{*}{$\begin{array}{c}\text { Rata-rata jumlah } \\
\text { benang yang } \\
\text { digunakan } \\
\text { (Average number of } \\
\text { utilized thread) } \\
\text { unit/pengrajin/tahun } \\
\text { (unit/handcrafter/ } \\
\text { year) }\end{array}$} & \multicolumn{2}{|c|}{$\begin{array}{l}\text { Tingkat pemanfaatan } \\
\text { per pengrajin per } \\
\text { tahun (Utilization } \\
\text { level of each } \\
\text { handcrafter per year) }\end{array}$} & \multirow[t]{2}{*}{$\begin{array}{c}\text { Estimasi tingkat } \\
\text { pemanfaatan } \\
\text { Kabupaten Sumba } \\
\text { Timur pada tahun } \\
2012 \text { (Utilization } \\
\text { level of Sumba Timur } \\
\text { District in year 2012) } \\
\text { Ton }\end{array}$} \\
\hline & & & & $\begin{array}{l}\text { Satuan lokal } \\
\text { (Local unit) }\end{array}$ & $\mathrm{Kg}$ & \\
\hline 1. & $\begin{array}{l}\text { Nila } \\
\text { (I. tinctoria L. ) }\end{array}$ & 2 karung & 4,5 & 9 karung & 18 & 49,34 \\
\hline 2. & $\begin{array}{l}\text { Mengkudu } \\
\text { (M.citrifolia) }\end{array}$ & 2 karung & 4,5 & 9 karung & 90 & 246,69 \\
\hline 3. & $\begin{array}{l}\text { Loba } \\
\text { (Symplocos sp.) }\end{array}$ & 20 ikat & 9 & $180 \mathrm{ikat}$ & 90 & 246,69 \\
\hline 4. & $\begin{array}{l}\text { Kemiri } \\
\text { (A. moluccana })\end{array}$ & $2 \mathrm{~kg}$ & 9 & - & 18 & 49,34 \\
\hline
\end{tabular}

Sumber (Source): Data primer (Primery data)

Keterangan(Remarks): 1 karung hijauan nila beratnya $\pm 2 \mathrm{~kg}$ (weight of 1 sack of nila biomass is about $2 \mathrm{~kg}$ )

1 karung akar mengkudu beratnya $\pm 10 \mathrm{~kg}$ (weight of 1 sack of mengkudu roots is about $10 \mathrm{~kg}$ )

1 ikat (kecil) loba beratnya $\pm 0,5 \mathrm{~kg}$ (weight of 1 bunch of loba is about $0,5 \mathrm{~kg}$ )

dapat diprediksi kapasitas produksi tahun 2012 yaitu sebanyak 99.043 lembar. Diasumsikan bahwa produk yang dihasilkan setengahnya (49.522 lembar) berupa sarung dan setengahnya (49.522 lembar) berupa kain, sedangkan produk selendang diabaikan karena ukurannya kecil dan tidak semua pengrajin memproduksinya. Dari wawancara dengan pengrajin diketahui bahwa rata-rata satu unit benang menghasilkan empat lembar sarung atau tiga lembar kain. Dari asumsi dan data di atas dapat dihitungjumlah benang yang digunakan untuk menghasilkan produk tersebut (Tabel 4).

Data pada Tabel 4 menunjukkan bahwa jumlah benang yang dipakai adalah 28.888 unit. Selanjutnya diasumsikan bahwa setengah (14.444 unit) dari benang tersebut diwarnai biru atau hitam menggunakan pewarna jenis nila dan setengahnya (14.444 unit) diwarnai merah menggunakan pewarna jenis mengkudu. Jenis loba dan 
Tabel(Table)4. Jumlah unit benang yang diperlukan untuk memproduksi 99.043 lembar produk tenun ikat (Number of thread units needed to produce 99.043 pieces of cloth woven product)

\begin{tabular}{lccc}
\hline $\begin{array}{c}\text { Jenis produk } \\
\text { (Type of product) }\end{array}$ & $\begin{array}{c}\text { Jumlah produk (lembar) } \\
\text { (Number of product } \\
\text { (pieces)) }\end{array}$ & $\begin{array}{c}\text { Jumlah produk per unit } \\
\text { benang (lembar) } \\
\text { (Number of product per unit } \\
\text { of thread (pieces)) }\end{array}$ & $\begin{array}{c}\text { Jumlah benang yang } \\
\text { terpakai (unit) (Number } \\
\text { of thread used (unit) }\end{array}$ \\
\hline Sarung (Sheath) & 49.522 & 4 & 12.381 \\
Kain (Cloth) & 49.522 & 3 & 16.507 \\
\hline Jumlah (Total) & - & - & 28.888 \\
\hline
\end{tabular}

Sumber (Source): Diolah dari data lapang (Compiled and analyzed from field data)

kemiri digunakan untuk semua benang karena fungsinya sebagai pengikat atau pengawet warna dan pelembut kain. Dengan demikian, tingkat pemanfaatan biomassa tumbuhan penghasil warna dapat diestimasi seperti disajikan pada Tabel 5.

Data pada Tabel 5 menunjukkan bahwa tingkat pemanfaatan biomassa nila dan mengkudu untuk Kabupaten Sumba Timur pada tahun 2012 bertutut-turut adalah 57,78 ton dan 288,88 ton. Selanjutnya tingkat pemanfaatan loba dan kemiri pada tahun yang sama adalah 288,88 dan 57,78 ton per tahun. Angka-angka tersebut sedikit lebih tinggi (14,61\% untuk nila dan kemiri; $14,60 \%$ untuk mengkudu dan loba) dibandingkan tingkat pemanfaatan biomassa empat jenis tumbuhan penghasil warna tersebut yang dihitung dengan cara pertama (seluruhnya dari data primer hasil wawancara dengan pengrajin). Artinya kedua cara estimasi tersebut dapat digunakan dengan derajad kesalahan 7,3\% (kecil dari 10\%).

\section{Teknik pemungutan}

Bahan baku pewarna alam yang berasal dari beberapa jenis tumbuhan umumnya diambil atau dipungut dari alam. Masih sangat sedikit, bahkan dapat dikatakan belum ada upaya penanaman atau budidaya jenis-jenis tersebut yang sudah dilakukan. Pengamatan lapang dan diskusi dengan pengrajin menunjukkan bahwa cara pemungutan bahan pewarna tersebut nampaknya tidak atau kurang lestari (sustain) dan cenderung merusak. Misalnya pemungutan akar mengkudu dilakukan dengan menggali tanah dan memotong akar pada satu sisi. Idealnya, akar pada sisi yang lain akan dipungut jika diperkirakan akar yang sudah di-potong pada satu sisi sudah tumbuh kembali. Namun kondisi ideal tersebut sulit dicapai karena pemungut tidak hanya satu, dua atau tiga orang. Jumlah pemungut akar mengkudu cukup banyak, sehingga sebatang mengkudu yang akarnya pada satu sisi belum pulih, akar pada sisi yang lain sudah dipungut pula. Hal ini tentu menyebabkan kematian pada pohon mengkudu. Akibatnya populasi mengkudu yang tumbuh di padang-padang (kawasan savana) semakin menurun dan dikhawatirkan semakin lama akan semakin langka. Informasi dari sebagian besar responden bahwa ketersediaan populasi pohon mengkudu di alam semakin sedikit dan lokasinya semakin jauh dari rumah, mencapai 5-15 km. Demikian pula halnya dengan teknik pemungutan kulit batang dadap (Erytrina sp.) sebagai bahan campuran ekstrak akar mengkudu (Gambar 1).

Kulit batang dan daun loba (Symplocos sp.), sebagai bahan campuran pewarna, diperoleh pengrajin dengan cara membelinya dari pedagang atau pemungut (Gambar 2). Umumnya responden mengeluhkan harga kulit batang dan daun loba yang semakin mahal. Hal ini diduga karena bagian tumbuhan ini dipungut dari kawasan hutan (Taman Nasional Laiwanggi Wanggameti), dimana populasinya sudah semakin menurun. Pemanfaatan secara terus menerus tanpa ada upaya budidaya tentu akan mengancam kelestarian populasi loba di kawasan taman nasional tersebut dan akan menurunkan luas tutupan hutan. Cunningham et al. (2011b) melaporkan bahwa dalam periode lima tahun harga jual biomasa loba di Nusa Tenggara Timur mengalami peningkatan sebesar 335\% sebagai akibat berkurangnya pasokan karena degradasi hutan loba. Kinnaird et al. (2003) melaporkan bahwa laju kehilangan hutan di Sumba Timur cukup tinggi yaitu ratarata 6.000 ha per tahun. Luas tutupan hutan pada tahun 2003 kurang dari 7\% dari total luas lahan yaitu hanya $71.300 \mathrm{ha}$.

\section{Analisis kebutuhan, tingkat ketersediaan dan upaya budidaya}

Berdasarkan perhitungan tingkat pemanfaatan biomassa empat jenis tumbuhan pewarna utama dan berdasarkan informasi produksi hijauan yang ada, dapat diproyeksikan kebutuhan populasi tumbuhan tersebut (Tabel 6) dan upaya yang 
Tabel(Table)5. Estimasi penggunaan biomassa empat jenis tumbuhan penghasil warna berdasarkan data kapasitas produksi tahun 2012 di Kabupaten Sumba Timur (Utilization level estimated of biomass of four plant species produce natural dye based on production capacity data on year 2012 in East Sumba District)

\begin{tabular}{|c|c|c|c|c|c|}
\hline \multirow[t]{2}{*}{ No. } & \multirow[t]{2}{*}{$\begin{array}{c}\text { Jenis } \\
\text { (Species) }\end{array}$} & \multirow{2}{*}{$\begin{array}{l}\text { Jumlah benang } \\
\text { yang digunakan (unit) } \\
\text { (Number of } \\
\text { thread have been } \\
\text { used (unit)) }\end{array}$} & \multicolumn{2}{|c|}{$\begin{array}{l}\text { Tingkat pemanfaatan } \\
\text { per unit benang } \\
\text { (Utilization level for } \\
\text { each thread unit) }\end{array}$} & \multirow{2}{*}{$\begin{array}{c}\text { Tingkat pemanfaatan } \\
\text { Kabupaten Sumba Timur } \\
\text { pada tahun } 2012 \\
\text { (Utilization level of East } \\
\text { Sumba District in year 2012) } \\
\text { Ton }\end{array}$} \\
\hline & & & $\begin{array}{l}\text { Satuan lokal } \\
\text { (Local unit) }\end{array}$ & $\mathrm{Kg}$ & \\
\hline 1. & $\begin{array}{l}\text { Nila } \\
\text { (I. tinctoria L.) }\end{array}$ & 14.444 & 2 karung & 4 & 57,78 \\
\hline 2. & $\begin{array}{l}\text { Mengkudu } \\
\text { (M. citrifolia) }\end{array}$ & 14.444 & 2 karung & 20 & 288,88 \\
\hline 3. & Loba (Symplocos sp.) & 28.888 & 20 ikat & 10 & 288,88 \\
\hline 4. & Kemiri (A. moluccana) & 28.888 & - & 2 & 57,78 \\
\hline
\end{tabular}

Sumber (Source): Data primer (Primery data)

Keterangan (Remarks): 1 karung nila beratnya $\pm 2 \mathrm{~kg}$ (Weight of 1sack nila is about $2 \mathrm{~kg}$ )

1 karung mengkudu beratnya $\pm 10 \mathrm{~kg}$ (Weight of 1 sack mengkudu is about $10 \mathrm{~kg}$ )

1 ikat (kecil) loba beratnya $\pm 0,5 \mathrm{~kg}$ (Weight of 1 bunch of loba is about $0,5 \mathrm{~kg}$ )

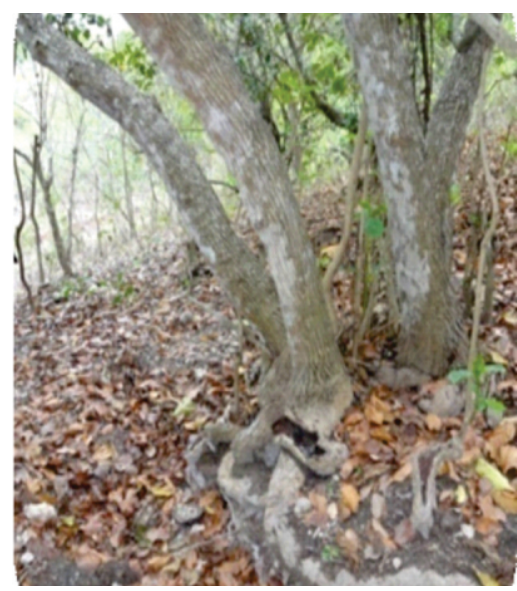

A

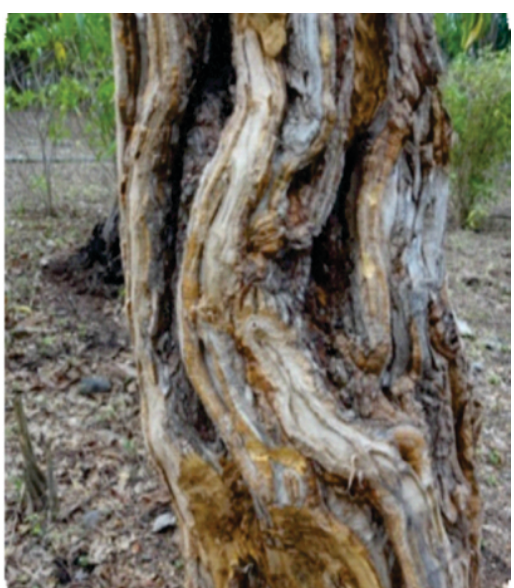

B

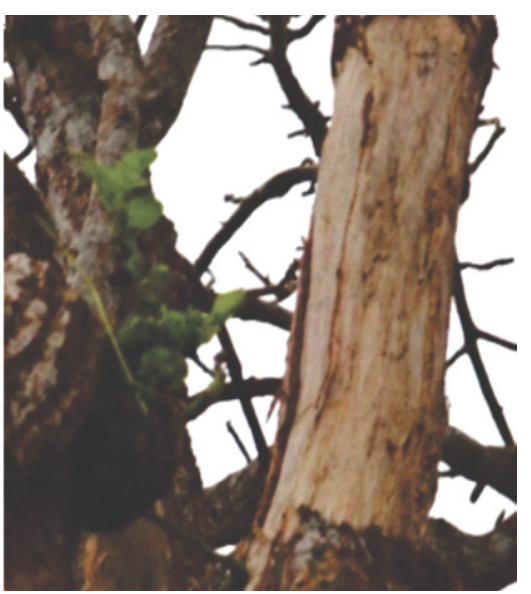

C

Sumber (Source): Murniati (2013)

Gambar(Figure) 1. Beberapa contoh cara pemungutan bagian tumbuhan penghasil warna di lokasi penelitian, A: Pohon mengkudu (Morinda citrifolia) dengan akarnya yang dipotong, B dan C: Pohon dadap (Erytrina sp.) dengan kulit batangnya yang dikupas (Some examples of gathering method of plant parts produce natural dye at the research site, A: Morinda citrifolia tree with the roots have been cut, $B$ and $C$ : Erytrina sp. trees with peeled bark)

perlu dilakukan untuk memenuhinya.

Nila tumbuh secara alami di kebun atau di padang-padang. Setelah hijauannya dipanen, biji nila yang jatuh dan atau disebar pengrajin akan tumbuh kembali. Sekalipun data potensinya tidak tersedia, sebagian besar responden mengatakan bahwa mereka tidak kesulitan dalam mendapatkan hijauan nila. Namun demikian budidaya nila tetap perlu dilakukan terutama untuk tujuan ko- leksi. Penanaman nila dapat dilakukan di Hutan Penelitian Hambala yang dikelola oleh Balai Penelitian Kehutanan Kupang yang berlokasi di Km 8 dari Kota Waingapu; dan dapat pula ditanam di lahan-lahan komunal di sentra produksi kerajinan tenun ikat seperti di Kelurahan Lambanapu dan Mauliru.

Kebutuhan biomassa (pepagan akar) mengkudu cukup besar yaitu 246,69 ton per tahun de- 


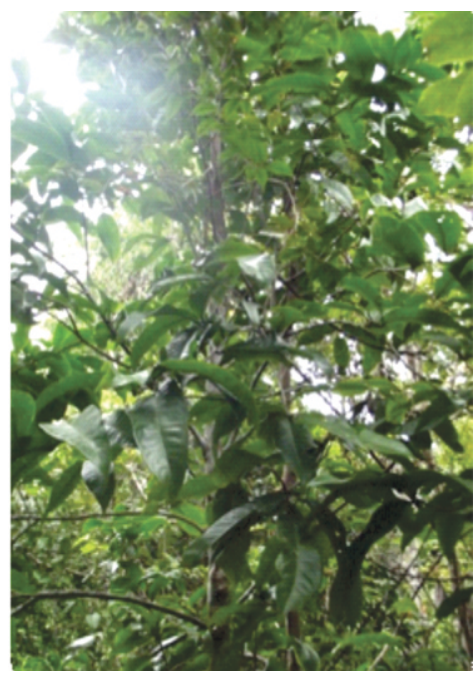

A

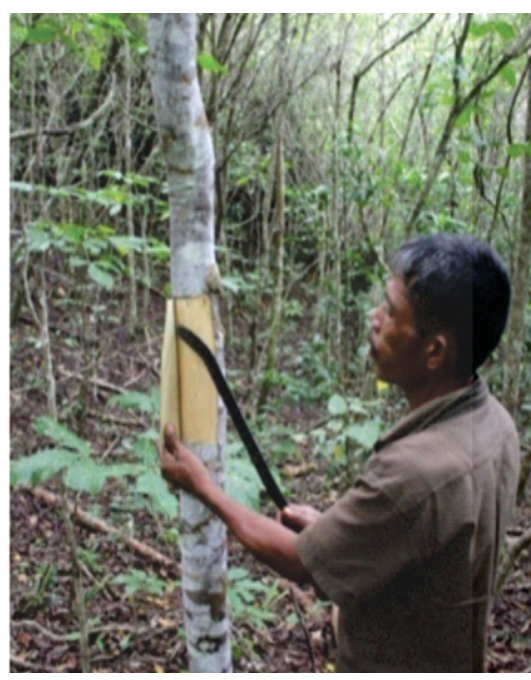

B

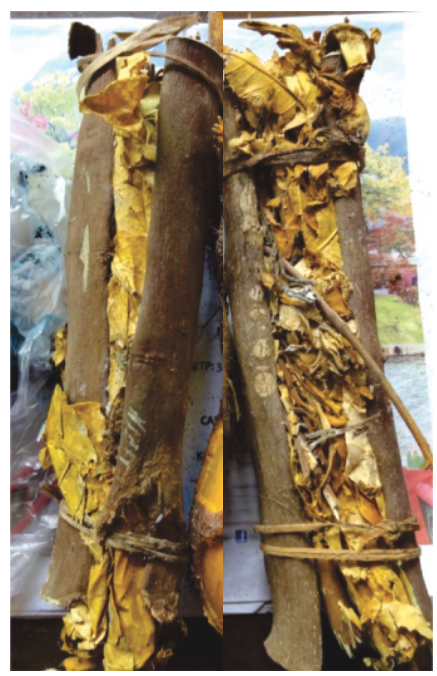

$\mathrm{C}$

Sumber (Source): Adan (and) B. Herry (2013), C. Takandjandji (2014)

Gambar(Figure) 2. Pohon loba (Symplocos sp.) di Taman Nasional Laiwanggi Wanggameti (A), pemungutan kulit batang loba (B), kulit batang dan daun loba yang sudah kering sebagai bahan pewarna (C). Foto A dan B oleh Hery, 2013(Symplocos sp. tree at Laiwanggi Wanggameti National Park (A), gathering of the bark (B), the bark and the leave as natural dye. Photo A and B by Hery, 2013)

ngan estimasi kebutuhan budidaya seluas hampir 500 ha. Namun jika dibandingkan dengan jumlah unit usaha kain tenun, dimana pada tahun 2012 jumlahnya 2741 unit, maka masing-masing pengrajin hanya perlu menanam seluas $\pm 0,2$ ha. Karena di alam pohon mengkudu juga masih tersedia (namun data potensinya tidak tersedia), maka jika pengrajin hanya dapat menanam setengah dari kebutuhan tersebut yaitu hanya 0,1 ha di kebun atau pekarangan mereka, upaya budidaya tersebut pun sudah sangat berarti untuk keberlanjutan usaha kain tenun ikat di Kabupaten Sumba Timur. Dengan penanaman tumbuhan penghasil warna di pekarangan pengrajin, maka

Tabel (Table) 6. Tingkat pemanfaatan dan proyeksi kebutuhan budidaya tumbuhan penghasil warna di Kabupaten Sumba Timur (Utilization level and projection of plantation needed of plant produce natural dye in East Sumba District)

\begin{tabular}{|c|c|c|c|c|}
\hline No. & $\begin{array}{l}\text { Jenis } \\
\text { (Species) }\end{array}$ & $\begin{array}{c}\text { Tingkat } \\
\text { pemanfaatan } \\
\text { tahun } 2012 \text { (ton) } \\
\text { (Utilization level } \\
\text { in year } 2012 \text { (ton)) }\end{array}$ & $\begin{array}{c}\text { Produksi hijauan } \\
\text { (Biomass } \\
\text { production) }\end{array}$ & $\begin{array}{l}\text { Kebutuhan } \\
\text { budidaya } \\
\text { (Plantation } \\
\text { requirement) }\end{array}$ \\
\hline 1. & $\begin{array}{l}\text { Nila } \\
\text { (I. tinctoria } \text { L.) }\end{array}$ & 49,34 & 8,4 ton/ha* & 5,87 ha \\
\hline 2. & $\begin{array}{l}\text { Mengkudu } \\
\text { (M. citrifolia) }\end{array}$ & 246,69 & $500 \mathrm{~kg} / \mathrm{ha}^{* *}$ & 493,38 ha \\
\hline 3. & $\begin{array}{l}\text { Loba } \\
\text { (Symplocos sp.) }\end{array}$ & 246,69 & $99 \mathrm{~kg} / \mathrm{ha} * * *$ & $2.492 \mathrm{ha}$ \\
\hline 4. & $\begin{array}{l}\text { Kemiri } \\
(\text { A. moluccana })\end{array}$ & 49,34 & $\begin{array}{c}27,5 \\
\mathrm{~kg} / \text { pohon } * * * * \\
(\text { tree })\end{array}$ & 1.794 pohon/trees \\
\hline
\end{tabular}

Sumber (Source): * Herdiawan \& Krisnan (2014)

**Lemmens \& Wulijarni-Soetjipto (1999)

$* * *$ Hadi (2013), diolah (processed)

****Krisnawati et al. (2011), dengan asumsi bahwa rendemen daging buah kemiri dari buahnya adalah 50\% (Assumption that rendement of candle nut fleshof fruit is 50\%). 
akses me-reka terhadap sumber pewarna lebih mudah. Untuk itu perlu dilakukan pelatihan teknik budi-daya jenis-jenis tumbuhan penghasil warna. Se-lain dengan cara tersebut, penanaman mengkudu dapat pula dilakukan pada program Hutan Kema-syarakatan (HKm) dan atau Hutan Desa (HD) yang sudah mulai dikembangkan di Kabupaten Sumba Timur.

Kebutuhan biomassa (pepagan batang) dan daun loba juga cukup besar, sama dengan kebutuhan pepagan akar mengkudu yaitu 246,69 ton per tahun. Karena produksi pepagan (kulit batang) dan daun loba relatif rendah yaitu hanya 99 $\mathrm{kg} / \mathrm{ha} /$ tahun (Hadi, 2013), maka prediksi kebutuhan budidaya sangat besar yaitu 2.492 ha. Selama ini pengrajin di Kabupaten Sumba Timur memperoleh pepagan dan daun loba dengan cara membelinya dari pedagang. Namun prospek pasar sampai saat ini belum didukung oleh informasi potensi produksi maupun produksi aktual pepagan dan daun loba, khususnya dari kawasan hutan di Kabupaten Sumba Timur. Untuk itu, perlu dilakukan penelitian tentang potensi produksi kulit batang loba dan rantai pemasaran atau tata niaganya. Selanjutnya upaya budidaya sudah sangat mendesak untuk dilakukan agar potensi populasi loba di taman nasional dapat dipertahankan agar tidak terus menurun dan usaha kerajinan tenun ikat dapat berkembang dan berkelanjutan. Hadi (2010) melaporkan bahwa tanaman loba sangat jarang dibudidayakan oleh masyarakat. Oleh sebab itu penanaman loba perlu diprogramkan pada Pembangunan $\mathrm{HKm}$ dan Hutan Desa di kawasan hutan dengan ketinggian $\geq 600 \mathrm{~m}$ dpl sesuai persyaratan tumbuh jenis loba.

Kebutuhan daging buah kemiri per unit usaha (pengrajin) adalah $18 \mathrm{~kg} /$ tahun (Tabel 3). Produksi buah pohon kemiri dewasa sesuai laporan Krisnawati et al., (2011) adalah $55 \mathrm{~kg}$ buah atau $27,5 \mathrm{~kg}$ daging buah/pohon/tahun. Jika masingmasing pengrajin mempunyai satu pohon kemiri dewasa dengan produksi yang hampir sama dengan yang dilaporkan di atas, maka kebutuhan terhadap buah kemiri untuk keperluan produksi tenun ikat di Kabupaten Sumba Timur akan terpenuhi. Jika dikembangkan dalam program HKm atau Hutan Desa diperlukan 1.794 pohon atau dibulatkan 2.000 pohon. Dengan menggunakan jarak tanam 8 × $8 \mathrm{~m}$ (pohon dewasa), diperlukan pertanaman kemiri hanya sekitar 13 ha.

\section{Penggunaan jenis tumbuhan sumber pe- warna alternatif}

Motif dan warna kain tenun ikat yang diproduksi saat ini bersifat tradisional dan umumnya digunakan untuk acara/upacara adat dan agama. Warnanya terbatas, merah dan hitam atau biru, dengan harga yang sangat mahal sehingga kurang terjangkau oleh masyarakat umum, terutama turis domestik. Banyak pihak berpendapat perlu mengembangkan motif dan warna kain tenun ikat. Pengembangan warna dimaksudkan untuk menggunakan atau menambahkan warna lain selain merah dan hitam atau biru. Hal ini berimplikasi pada diversifikasi penggunaan jenis tumbuhan penghasil warna sehingga tidak terbatas pada nila dan mengkudu, sehingga tekanan terhadap populasi mengkudu di alam dapat dikurangi. Warna merah dapat diperoleh dari jenis mahoni (Swietenia macrophylla King), tengar (Ceriops tagal) dan secang (Caesalpinia sappan L.). Tocharman (2009) melaporkan bahwa eks-trak kulit buah mahoni dapat menghasilkan warna cokelat kekuning-kuningan dan tidak mudah luntur, sedangkan kulit kayunya dapat menghasilkan warna merah kecokelatan. Jenis tanaman ini mudah diperoleh dan mudah tumbuh di wilayah Sumba Timur.

Demikian pula jenis loba sebagai bahan pencampur yang berfungsi sebagai mordan (garam logam) untuk bahan pengikat dalam pewarnaan kain perlu dicari jenis alternatifnya, namun yang dapat tumbuh di wilayah Sumba Timur dengan iklimnya yang kering. Salah satu jenis yang berfungsi sebagai pewarna mordan adalah Soga (Peltophorum pterocarpum (DC) Backer (Lemmens \& Wulijarni-Soetjipto (1999). Penulis sudah mencoba menanam jenis ini di demplot yang dibangun di Kecamatan Pahunga Lodu sebanyak 100 batang pada Februari 2014 dengan keberhasilan (persen tumbuh) pada umur empat bulan (pengamatan Juni 2014) sebesar 60\%. Selain jenis soga, penulis juga telah menanam mahoni dan kemiri dengan keberhasilan tumbuh masingmasing $65 \%$ dan 55\%. Beberapa jenis tumbuhan penghasil warna alternatif yang berpotensi dikembangkan di wilayah Kabupaten Sumba Timur disajikan pada Tabel 7.

\section{KESIMPULAN DAN SARAN}

\section{A. Kesimpulan}

Terdapat lima jenis tumbuhan yang banyak digunakan pengrajin tenun ikat di Kabupaten Sumba Timur sebagai sumber pewarna dan atau pengikat dan pengawet warna serta pelembut kain yaitu nila (Indigofera tinctoria L.), mengkudu (Morinda citrifolia L.), loba (Symplocos fasciculata Zoll), kemiri (Aleurites moluccana (L.) Willd.) dan dadap (Erytrina sp.). Kelima je- 
Tabel(Table) 7. Jenis-jenis tumbuhan penghasil warna alternatif yang berpotensi dikembangkan di wilayah Sumba Timur (Plant species alternative produced natural dye for coloring cloth potentially developed at Sumba Timur region)

\begin{tabular}{|c|c|c|c|c|}
\hline \multirow[b]{2}{*}{ No. } & \multicolumn{2}{|c|}{ Jenis tumbuhan (Plant species) } & \multirow[b]{2}{*}{$\begin{array}{c}\text { Bagian yang } \\
\text { dimanfaatkan } \\
(\text { Parts being used })\end{array}$} & \multirow[b]{2}{*}{$\begin{array}{c}\text { Warna yang } \\
\text { dihasilkan } \\
\text { (Produced colour) }\end{array}$} \\
\hline & $\begin{array}{l}\text { Nama daerah } \\
\text { (Local name) }\end{array}$ & $\begin{array}{l}\text { Nama ilmiah dan famili } \\
\text { (Scientific name and the } \\
\text { family) }\end{array}$ & & \\
\hline 1. & $\begin{array}{l}\text { Kayu kuning / Soga } \\
\text { tegeran }\end{array}$ & $\begin{array}{l}\text { Cudrania javanensis / } \\
\text { Moraceae }\end{array}$ & Kayu teras & Kuning \\
\hline 2. & Mahoni & $\begin{array}{l}\text { Swietenia macrophylla } \\
\text { King / Meliaceae }\end{array}$ & Kulit batang/buah & Merah ke coklatan \\
\hline 3. & Jambu mete & $\begin{array}{l}\text { Anacardium } \\
\text { occidentale/Anacardiaceae }\end{array}$ & Daun & Kuning muda \\
\hline 4. & Pinang & Areca catechu /Palmae & Buah & Kuning mas \\
\hline 5. & Tengar & $\begin{array}{l}\text { Ceriops tagal / } \\
\text { Rhizophoraceae }\end{array}$ & Pepagan dan getah & Merah dan hitam \\
\hline 6. & Secang & $\begin{array}{l}\text { Caesalpinia sappan L. / } \\
\text { Leguminoseae }\end{array}$ & Kayu & Merah \\
\hline 7. & Soga & $\begin{array}{l}\text { Peltophorum pterocarpum } \\
\text { Leguminoseae }\end{array}$ & Pepagan batang & $\begin{array}{l}\text { Cokelat kemerahan } \\
\text { dan sebagai mordan }\end{array}$ \\
\hline
\end{tabular}

Sumber (Source): Dari berbagai sumber (From various sources)

nis tumbuhan tersebut dipungut dari alam. Prediksi tingkat pemanfaatan biomassa nila dan mengkudu sebagai sumber pewarna utama di Kabupaten Sumba Timur masing-masing adalah 49,3 dan 246,7 ton per tahun. Pemanfaatan biomassa loba dan kemiri sebagai pengikat dan pengawet warna serta pelembut kain diprediksi berturut-turut 246,7 dan 49,3 ton per tahun.

Belum ada upaya budidaya jenis-jenis tumbuhan penghasil warna yang signifikan oleh pengrajin atau stakeholder terkait. Disisi lain, kebutuhan biomassa tumbuhan tersebut terutama mengkudu, loba dan kemiri terus meningkat. Kebutuhan ini harus diimbangi dengan upaya budidaya jenis-jenis tersebut dan pengenalan jenis-jenis pewarna alternatif.

\section{B. Saran}

Perlu dirancang upaya budidaya tumbuhan penghasil warna untuk menunjang industri tenun ikat yang berkelanjutan di Kabupaten Sumba Timur, melalui pelatihan teknik budidaya jenisjenis tumbuhan penghasil warna dan penyediaan bibitnya, menjadikan jenis-jenis tumbuhan tersebut sebagai komponen pada pengembangan Hutan Kemasyarakatan dan Hutan Desa serta pengenalan jenis-jenis tumbuhan penghasil warna alternatif.

\section{UCAPAN TERIMAKASIH}

Penulis menyampaikan terimakasih dan penghargaan setinggi-tingginya kepada Pusat Penelitian dan Pengembangan Konservasi dan Rehabilitasi atas dukungan dana melalui Dana DIPA Tahun 2013 dan 2014, sehingga penelitian ini dapat terlaksana. Terima kasih dan penghargaan kami sampaikan pula kepada semua pihak yang telah membantu pelaksanaan penelitian mulai dari pengamatan di lapangan, wawancara dan Focus Group Discussion dengan pengrajin serta pengumpulan data sekunder. Ucapan terima kasih khusus kami sampaikan kepada pengrajin kain tenun ikat di empat lokasi penelitian di Kabupaten Sumba Timur yaitu Kelurahan Lambanapu dan Mauliru, Desa Watu Hadang dan Kaliuda atas kerjasama dan informasi yang diberikan.

\section{DAFTAR PUSTAKA}

Adalina, Y. (2013). Pemanfaatan sumber pewarna alam sebagai zat warna nabati. Prosiding Gelar Teknologi Hasil Penelitian. Iptek untuk kesejahteraan masyarakat Sumba Barat (pp. 114-30). Pusat Penelitian dan Pengembangan Hutan dan Konservasi Alam. 
Adalina, Y., Herawati, T., \& Rosandy, A. (2013). Tumbuhan Indigofera sebagai pewarna alami kain tenun ikat di Nusa Tenggara Timur. Prosiding Gelar Teknologi Hasil Penelitian. Pengembangan hasil hutan non kayu dalam upaya mensejahterakan masyarakat Sumba Timur (pp. 97-108). Pusat Penelitian dan Pengembangan Hutan dan Konservasi Alam.

Banilodu, L., \& Saka, N.T. (1993). Analisis deskriptif hutan Pulau Sumba. Hasil Penelitian Ekspedisi Sumba 1992. Kerjasama antara Birdlife International-Indonesia Programme dan Direktorat Jenderal Perlindungan Hutan dan Pelestarian Alam (PHPA), Departemen Kehutanan, Universitas Katolik Widya Mandira, Kupang.

BPS Kabupaten Sumba Timur. (2012a). Indikator Kesejahteraan Rakyat Sumba Timur 2011, BPS Kabupaten Sumba Timur.

BPS Kabupaten Sumba Timur. (2012). Kabupaten Sumba Timur Dalam Angka 2012. BPS Kabupaten Sumba TImur.

Balai Pustaka dan Prosea. (1999). Sumber Daya Nabati Asia Tenggara No. 3. Tumbuh-tumbuhan penghasil pewarna dan tanin. Bogor: PT. Balai Pustaka, Jakarta bekerjasama dengan Prosea Indonesia.

Cunningham A.B., Maduarta, I.M., Howe, J., Ingram, W., \& Jansen, S. (2011a). Hanging by a Thread: Natural Metallic Mordant Processes in Traditional Indonesian Textiles. Economic Botany, 65(3), 241-259. The New York Botanical Garden Press.

Cunningham A.B., Ingram, W., Daoskadati, W., Howe, J., Sujatmoko, S., Refli, R., Liem, J.V., Tari, A., Maruk, T., Robianto, N., Sinlae, A., Ndun, Y., Maduarta, I.M., Hadi, D.S.\& Koeslulat, E. (2011b). Hidden Economies, future options: Trade in Non-timber forest products In Eastern Indonesia. ACIAR Technical Report No.77. Canberra: Australian Center for International Agricultural Research.

Dinas Kehutanan Sumba Timur. (2014). Data tentang luas kawasan hutan di Kabupaten Sumba Timur. Sumba Timur.

Dinas Perindustrian dan Perdagangan Kabupaten Sumba Timur. (2011). Data industri formal dan non formal, industri kecil dan industri menengah. Hasil pemutahiran data tahun 2011.
Gana, R. (2007). Program aksi pengembangan ternak kerbau di Kabupaten Sumba Timur, Nusa Tenggara Timur. Makalah pada Seminar dan Lokakarya Nasional Usaha Ternak Kerbau. Nusa Tenggara Timur: Dinas Peternakan Kabupaten Sumba Timur.

Hadi, D.S. (2013). Loba (Symplocos sp.) sebagai bahan mordant pewarnaan alami pada tenun tradisional di Nusa Tenggara Timur. Prosiding Gelar Teknologi Hasil Penelitian Iptek untuk Kesejahteraan Masyarakat Sumba Barat (pp. 31-40). Pusat Penelitian dan Pengembangan Konservasi dan Rehabilitasi.

Hadi, D.S., Prasetiyo, A.N., \& Pamungkas, D. (2010). Teknik konservasi dan domestikasi Loba (Symplocos sp.) sebagaiflora penghasil bahan pewarna alami. Data Penelitian. Balai Penelitian Kehutanan Kupang. Tidak dipublikasi.

Haning, Y. (2012). Ikat Weaving as Heritage for Sustainable Development in East Nusa Tenggara, Indonesia. Final Report on International Workshop (p. 56). International Institute for Asian Studies. Rapenburg 59, 2311 GJ Leiden, The Netherlands.

Heyne, K. (1987). Tumbuhan berguna Indonesia II. Jakarta: Badan Penelitian dan Pengembangan Kehutanan.

Herdiawan, I., \& Krisnan, R. (2014) Produktivitas dan pemanfaatan tanaman leguminosa Indigofera zollingeriana pada lahan kering. Wartazoa, 24(2).

Indrianingsih,A.W. \& Darsih, C. (2013). Natural dyes from plants extract and its applications in Indonesian Textile Small Medium Scale Enterprise. Technical Implementation Unit for Chemical Engineering Processes, 11(1), 16-22. Yogyakarta, Indonesian Institute of Sciences (UPT BPPTK- LIPI).

Kinnaird, M.F., Sitompul, A.F., Walker, J.S., \& Cahill, A.J. (2003). Pulau Sumba, Ringkasan Hasil Penelitian 1995-2002. Bogor. PHKA dan Wildlife Conservation Society-Indonesia Program.

Krisnawati, H., Kallio, M., \& Kanninen, M. (2011). Aleurites moluccana (L.) Willd. Ekologi, Silvikultur dan Produktivitas. Bogor, Indonesia: CIFOR. 
Kulkarni, S.S., Gokhale, A.V., Bodake, U.M., \& Pathade, G.R. (2011). Cotton dyeing with natural dye extracted from pomegranate (Punica granatum) Peel. Universal Journal of Environmental Research and Technology, $1(2), 135-139$.

Lemmens, R.H.M.J., \& Wulijarni-Soetjipto, N. (1992). Plant resources of South-East Asia No.3. Dye and tannin-producing plants. Bogor: Prosea.

nDima, P. P. (2007). Kajian budaya kain tenun ikat Sumba Timur. Program Pascasarjana Universitas Kristen Satya Wacana dan Pemerintah Daerah Kabupaten Sumba Timur. p. 244.

Prosea. (2009). Pewarna alami: Ditemukan 62 jenis tumbuhan penghasil pewarna alami. Akses tanggal 14 Maret 2014, dari http:// www.proseanet.org/prohati4/browser.php? pcategory $=2 \&$ pageset $=1$ ).
Subagiyo, Y.P. (2008). Tekstil tradisionil, Pengenalan bahan dan teknik. Bekasi: Studio Primastoria.

Tocharman, M. (2009). Eksperimen zat pewarna alami dari bahan tumbuhan yang ramah lingkungan sebagai alternatif untuk pewarnaan kain batik. Bandung: Universitas Pendidikan Indonesia.

Umroni, A. (2010). Mengenang Hari Keanekaragaman Hayati International. Warta Cendana, III (1), 4-8. Balai Penelitian Kehutanan Kupang.

Wanyama, P.A.G., Kiremire, B.T., \& Murumu, J.E.S. 2014. Extraction, characterization and application of natural dyes from selected plants in Uganda for dyeing of cotton fabrics. African Journal of Plant Science, 8(4), 185195. 
Lampiran(Appendix) 1. Jenis-jenis tumbuhan yang dimanfaatkan sebagai pewarna kain tenun ikat di lokasi penelitian (Plant species used as natural dye for coloring cloth at the research site)

\begin{tabular}{|c|c|c|c|c|}
\hline \multirow[b]{2}{*}{ No. } & \multicolumn{2}{|c|}{ Jenis tumbuhan (Plant species) } & \multirow{2}{*}{$\begin{array}{c}\text { Bagian yang } \\
\text { dimanfaatkan } \\
\text { (Parts being used) }\end{array}$} & \multirow{2}{*}{$\begin{array}{c}\text { Warna yang } \\
\text { dihasilkan } \\
\text { (Produced colour) }\end{array}$} \\
\hline & $\begin{array}{l}\text { Nama daerah } \\
\text { (Local name) }\end{array}$ & $\begin{array}{c}\text { Nama ilmiah } \\
\text { (Scientific name) }\end{array}$ & & \\
\hline 1. & Wora atau nila & Indigofera tinctoria $\mathrm{L}$. & Daun, batang, biji & Biru-hitam \\
\hline 2. & Kombu atau mengkudu & Morinda citrifolia L. & Akar & Merah \\
\hline 3. & Loba & Symplocos sp. & $\begin{array}{l}\text { Kulit batang/cabang } \\
\text { (pepagan) dan daun } \\
\text { kering }\end{array}$ & $\begin{array}{l}\text { Pengikat warna } \\
\text { (mordan) }\end{array}$ \\
\hline 4. & Kawilu atau kemiri & $\begin{array}{l}\text { Aleurites moluccana }(\mathrm{L} .) \\
\text { Willd. }\end{array}$ & Daging buah & $\begin{array}{l}\text { Penguat/pengawet } \\
\text { warna }\end{array}$ \\
\hline 5. & Walakari atau dadap & Erythrina sp. & $\begin{array}{l}\text { Kulit batang (bagian } \\
\text { dalam) }\end{array}$ & Pelembut kain \\
\hline 6. & Kayu Kuning & $\begin{array}{l}\text { Cudrania javanica } \\
\text { Blume }\end{array}$ & Batang & Kuning \\
\hline 7. & Tada rongu atau kapuk & Ceiba petandra $\mathrm{L}$. & Kulit & Pengikat warna \\
\hline 8. & Koleng susu atau widuri & Calotropis gigantea $\mathrm{L}$. & Akar & Pengikat warna \\
\hline 9. & Karara atau sukun & $\begin{array}{l}\text { Artocarpus communis } \\
\text { Forst }\end{array}$ & Daun & Pengikat warna \\
\hline 10. & Wingir atau kunyit & $\begin{array}{l}\text { Curcuma domestica } \\
\text { Linn. }\end{array}$ & Rimpang & Kuning \\
\hline 11. & Winnu atau pinang & Areca catechu L. & Buah & Coklat \\
\hline 12. & $\begin{array}{l}\text { Mbaku hawu atau cabe } \\
\text { rawit }\end{array}$ & Capsicum frutescens $\mathrm{L}$. & Akar & Pengikat warna \\
\hline 13. & Rapaita atau paria & Momordica charantia $\mathrm{L}$. & Ranting & Pengikat warna \\
\hline 14. & Langira & Nauclea orientalis L. & Batang & Pengikat warna \\
\hline 15. & Paniatang atau arbila & Dolichos sp. & Daun & Pengikat warna \\
\hline 16. & $\begin{array}{l}\text { Kanduru paita atau } \\
\text { terong }\end{array}$ & Solanum sp. & Akar & Pengikat warna \\
\hline 17. & Bakau & Rhizopora apiculata Bl. & Kulit batang & Pengikat warna \\
\hline 18. & Putri malu & Mimosa pudica & Daun & Kuning \\
\hline 19. & Pandan & Pandanus sp. & daun & Pengikat \\
\hline 20 & Cemara gunung & $\begin{array}{l}\text { Casuarina } \\
\text { junghuhniana L. }\end{array}$ & Kulit batang & Pengikat warna \\
\hline
\end{tabular}

Sumber (Source): Data primer (Primery data) 